University of Nebraska - Lincoln

DigitalCommons@University of Nebraska - Lincoln

1981

NATURAL AND APPLIED CONTROL OF INSECTS BY PROTOZOA1

J.E. Henry

Follow this and additional works at: https://digitalcommons.unl.edu/usdaarsfacpub

This Article is brought to you for free and open access by the U.S. Department of Agriculture: Agricultural Research Service, Lincoln, Nebraska at DigitalCommons@University of Nebraska - Lincoln. It has been accepted for inclusion in Publications from USDA-ARS / UNL Faculty by an authorized administrator of DigitalCommons@University of Nebraska - Lincoln. 


\section{NATURAL AND APPLIED CONTROL OF INSECTS BY PROTOZOA $^{1}$}

\section{J. E. Henry}

Rangeland Insect Laboratory, Agriculture Research, Science and Education Administration, USDA, Bozeman, Montana 59717

Protozoa have been recognized as important factors in the natural regulation of the densities of certain insects. However, they have been given little consideration as applied microbial agents because entomophilic species cause chronic or debilitative infections in a narrow range of hosts. From a control standpoint, and ultimately from an economic standpoint, they could not compete with the more rapid, broad spectrum action of chemical insecticides or the more virulent pathogens such as bacteria, viruses, and certain fungi. Protozoa appeared useful only when low levels of pests could be tolerated, as in forests.

Gradually, interest in protozoa as potential biological control agents has been increasing (98). Primarily, this is a result of pest management concepts that emphasize conservation and augmentation of existing natural control agents. This has been demonstrated by an increase in published research reports on applied use of protozoan microbial agents, along with some excellent reviews of certain aspects of protozoa $(8,9,77,78,98)$. The body of literature dealing with natural and applied control by protozoa now is so extensive that no single review can provide a fully comprehensive treatment of the subject. Since the review by McLaughlin (77) provided a fairly complete assessment of the subject prior to 1970 it seems appropriate that it should serve as a starting point for this review in order to demonstrate the progress over the past decade.

'The US Government has the right to retain a nonexclusive, royalty-free license in and to any copyright covering this paper. 
A comment is necessary on the systematics of this very diverse group. In several recent schemes the Microsporida were given phylum rank as Microspora, thereby removing this group from Protozoa $(36,97)$. Although there are basic differences between the Protozoa and Microspora, many researchers use the traditional nomenclature of Microsporida or Microsporidia; for the purpose of continuity with prior reviews, microsporidia will be treated here as part of the Protozoa.

\section{NATURAL CONTROL BY PROTOZOA}

\section{Ciliates}

Most entomophilic ciliates are associated with dipterans, primarily mosquitoes and chironomids. Although there have been reports of fairly high incidence of ciliates in certain insects, for example $43.2 \%$, epizootics that have controlled insect populations have not been reported (77). Moreover, because of the low pathogenicity, there seems to be little potential for using ciliates against noxious insects. For example, only two ciliates were found during a five-year survey of protozoa in insects in Poland, neither of which appeared pathogenic to their hosts (64).

\section{Flagellates}

Most entomophilic flagellates belong to the order Kinetoplastida of the superclass Mastigophora. The association with insects varies, ranging from mutualism and commensalism to apparent parasitism (8). Many are digenetic and spend part of their life cycle in an insect, most often Hemiptera or Diptera, and part in other animals or plants. The immediate and long-term effects of flagellates on insects are poorly understood and there has been no effort to use them against insects.

Several epizootics by flagellates have been reported. One was caused by Herpetomonas swaine i in a population of the sawfly Neodiprion swainei in an eastern forest region of Canada (94). The flagellate was observed in $86 \%$ of the sawfly larvae collected from 10-15 year-old moderately infested jack pines. Infections occurred in all larval instars, eonymphs, and adults. The parasites were most abundant in third and fourth instar larvae, but mortality never exceeded $20 \%$ or occurred before the fourth and fifth instar; it occurred only among those that contracted the infection as first or second instar larvae. Although the amount of fat tissue in larvae was reduced, the adults exhibited no gross symptoms of infection nor lowered fecundity and there was no effect on simultaneous infections by an inclusion body virus. The flagellate could not be transmitted to the insects Galleria mellonella, Archips cerasivoranus, Malacosoma disstria, Pristiphora erichsonii, and the earthworm Lumbricus terrestris. Crithidia cimbexi shows a similar lack of 
pathogenicity in the sawfly Cimbex americana and did not infect other insects (69).

More recently, the flagellate Blastocrithidia caliroae was isolated from quarantined eonymphs of the pear-slug Caliroa cerasi during introduction of parasites of the slug into New Zealand (67). Infections were observed at several locations in Europe where high mortalities were noted among pear slugs that contained high concentrations of flagellates. The infections were observed in all stages except the first instars and adults; most mortality occurred during the fourth, fifth, and sixth instars. Young infected larvae appeared normal, but older nymphs experienced a drying of the mucous coating that resulted in a darkening and spotty general appearance. Although infections were not observed among adult pear slugs, the organism might be transmitted vertically during reproduction.

One epizootic occurred during an outbreak of the pear slug in the upper Rhine Valley in Germany. Of the 2500 insects collected and reared to eonymphs, $53 \%$ died, and of these, $90 \%$ contained flagellates. During another epizootic in Germany, pear slugs collected for shipment suffered $42 \%$ mortality among eonymphs in August 1972, but $74 \%$ mortality in November 1972. The field population began collapsing in late 1972 and declined to endemic levels in 1973.

Also in Europe, the flagellate Herpetomonas chatoni was observed in several noctuid adults (Discestra trifolii, Agrotis exclamationis, and A. segetum) caught in light traps (65). The incidence of infection within each species varied during the three seasons of the survey, but never exceeded $8 \%$.

\section{Coccidia}

Adelina tribolii, which infects several stored product pests and causes striking epizootics in populations of the confused flour beetle, Tribolium confusum, is probably the most frequentiy encountered coccidian in insects (77). Infection rates of $68 \%$ have been reported (64), indicating that this coccidian is an important factor in the regulation of laboratory and natural populations of Tribolium spp. Also, an epizootic by a species of Adelina in a laboratory colony of the wax moth, Galleria mellonella, suggested that the coccidian might be used to control wax moths in bee hives (4). Recently, the coccidian Rasajeyna nannyla was described from the European crane fly, Tipula paludosa (5). An investigation of the seasonal cycles of the coccidian revealed that the incidence of $R$. nannyla was higher in Tipula vittata than in $T$. paludosa at a site where part of the study area was constantly under water (6). In this habitat, which was more suitable for $T$. vittata than for $T$. paludosa, coccidian oocysts were protected from both freezing and desiccation in pools of water that were not completely frozen. 
Thus, inoculum was available throughout the year. Analysis of the infection data confirmed that the incidence of infection was a function of the temperature differences between the habitats (7). Although the incidence of infection by $R$. nannyla in these crane flies reached levels of nearly $100 \%$, there was no evidence of host density regulation.

\section{Amoebidae}

As pointed out by McLaughlin (77), Malameba locustae, which infects grasshoppers and some crickets, is probably the most important entomophilic amoeba from the standpoint of natural or applied control of a host. This was demonstrated in reports of a high natural incidence of $M$. locustae in the brown locust, Locustana pardalina (59); in one instance $M$. locustae prevented an outbreak of this locust in one area of South Africa (102).

Most recent studies of $M$. locustae examine control of the amoeba in laboratory colonies of grasshoppers $(16,17,37,44)$ or discuss the structural aspects of amoeba development as a basis for proper taxonomic assignment $(19,30,32,33)$. Infections by $M$. locustae also have been observed in silverfish (Thysanura) from a colony that was started with insects collected in a culture room containing desert locusts, Schistocerca gregaria, that were heavily infected with the amoeba (58).

\section{Eugregarines}

The eugregarines are probably the most frequently encountered protozoa in insects and the most innocuous. Many species of cephaline gregarines have been reported, particularly in the genus Gregarina, but few cause pathogenic effects in the host. Moderate infestations of the gregarine Gregarina garnhami reduced the weights of male fledglings (new adults) of $S$. gregaria without causing observable effects on molting or feeding (31). Anderson \& Magnarelli (1) reported that $85 \%$ of larvae of the deerfly Chrysops fuliginosus were infected with the eugregarine Cometoides pechumani during the summer, but only 30 to $58 \%$ were infected during the winter. Less than $7 \%$ of the adults of this species were infected, as was one pupa of Chrysops atlanticus. In a similar study of protozoa in stored product insects in California, $4.3 \%$ of all insects of 6 species of Trogoderma collected at 322 locations over a four-year period were infected with a eugregarine Pyxinia sp. (28). Thus there is evidence that eugregarines might affect the growth of insects and can occur at high frequencies; however, critical tests have not been conducted on possible long-range effects of such infestations upon insect densities.

In an interesting case of competition, gregarines in the mosquito Aedes aegypti interfered with the development of dog heart worm, Dirofilaria immitis, for which the mosquito serves as a vector (95). The gregarine 
trophozoites destroyed epithelial cells of the digestive tract and Malpighian tubules, which resulted in fewer cells available for filarial growth. Also, the Malpighian tubules of infected mosquitoes were shorter and deformed and the weights of infected pupae were significantly lower than those of uninfected pupae.

\section{Neogregarines}

Neogregarines have been reported from Lepidoptera, Coleoptera, and Orthoptera. Some species exhibit high pathogenicity and control potential (78), which undoubtedly can be attributed to one or more reproductive cycles in the life of these organisms (8). However, only a few studies have provided information on the natural occurrence and possible control of insect populations. The two neogregarines that have received the most attention are Mattesia grandis, described from the boll weevil, Anthonomus grandis (76), and Mattesia trogodermae, described from the khapra beetle, Trogoderma granarium (13). One study of the natural frequency of $M$. trugodermae showed $80 \%$ infection in seven species of beetles collected during a four-year period from 322 stored products facilities in California (28).

\section{Microsporidia}

Although the microsporidians are among the most common pathogens in insects under natural conditions, both the number of epizootic studies and field applications have been limited (98). However, this is changing rapidly and some recent studies of natural control by microsporidia provide basic information for prediction of population collapses and for applied use of the pathogens.

FOREST AND TREE CROP PESTS Early studies provided information on the host-pathogen relationship between the spruce budworm, Choristoneura fumiferana, and the protozoan Nosema fumiferanae in the pine forests of Ontario (77). Larvae that are infected early in their development from parental infections fail to mature and die. Their frass and cadavers then provide a source of spore inoculum for fourth and fifth instar nymphs that complete development but are infected in the adult stage. Adults also may contract the disease by consuming spores. Thus, increased incidence of infection usually stems from consuming food contaminated with spores, but vertical transmission maintains the microsporidium in the host population. For example, from 1955 to 1958 the incidence of disease increased progressively from 36.5 to $56.1 \%$ and the population collapse was attributed to the depressing effect of the microsporidium. Wilson (106) monitored the infection rates in $C$. fumiferana populations that had been studied some years 
before when infection rates increased from 36.4 to $81.3 \%$ over a five-year period (99). Beginning about four years later and extending over a period of five years, Wilson (106) observed an increase in infection from about 36 to $69 \%$. The results of a three-year study at another location in Ontario demonstrated similar infection patterns (104). At a point when 80 to $90 \%$ of the budworms had pupated, $66.6 \%$ of the larvae and $46.6 \%$ of the pupae were infected during the second year and $87.5 \%$ of larvae and $81.4 \%$ of pupae were infected during the third year.

The green tortrix, Tortrix viridana, caused widespread defoliation of two species of oaks in Germany during 1967; this threatened to deform the oaks and thus reduce their value for producing high quality veneer and acorns (22). Surveys conducted in 1968 just before applications of DDT or Bacillus thuringiensis established that $29 \%$ of the first instar larvae were infected with microsporidian parasites. After the treatments, $59 \%$ of the larvae in check plots were infected compared to $41 \%$ in plots treated with $B$. thuringiensis and $31 \%$ in plots treated with DDT. Infection rates among adults were 60,58 , and $42 \%$, respectively. Although these infection rates resulted in about $75 \%$ reduction in tortrix densities, the infestation remained above the economic threshold. During the following season, $60 \%$ of the first instar larvae were infected with microsporidia. Subsequently, $80 \%$ of the third instar larvae were infected and no visible defoliation occurred. Sampling two weeks later during the fifth instar stage confirmed that the population had collapsed and that the incidence of infection had decreased to $24 \%$ in untreated plots. Also, infections decreased in plots treated with $B$. thuringiensis and DDT from 34 and $40 \%$ to 7 and $10 \%$, respectively. These results suggested that the treatments may not have been necessary and that subsequent epizootics might be predicted by monitoring infections. Nosema tortricis was the most common microsporidium (43.6\%) involved in the epizootic, along with Octosporea viridanae $(0.6 \%)$, Thelohania weiseri (0.4\%), and Plistophora sp. (1.2\%).

Another epizootic by microsporidia on populations of the green tortrix occurred in southern Poland (68). During the first two years, 30 and 26\%, respectively, of the larvae on the oak trees were infected and 48.5 and $49.2 \%$, respectively, died during rearing after removal from the trees. However, during the first year only $14 \%$ mortality was due to microsporidiosis; the remainder was due to bacterial infections. During the second year all mortality was attributed to microsporidia. During the third year the incidence of infection was about the same, $31.8 \%$, but mortality increased to $91.1 \%$. The population then collapsed and green tortrix larvae were difficult to locate during the two subsequent seasons. Of the 54 and 72 larvae collected during the fourth and fifth years, respectively, none were infected. The progression of the epizootic appeared to be due to increasing infection 
rates among adults and subsequent transovarial transmission. For example, during the second season $12 \%$ of the adults were infected, whereas in the third season just prior to the collapse, $65 \%$ of the adults were infected. Not only did this epizootic follow the same general course as that in Germany, but the same four microsporidia were involved. However, in the latter epizootic $O$. viridanae was most prominent (30\%), followed by $N$. tortricis (15\%) and $T$. weiseri (10\%). Only two larvae were observed with Plistophora $\mathrm{sp}$.

A study in the Soviet Union of the natural occurrence of microsporidia in the codling moth, Laspeyresia pomonella, revealed that Nosema carpocapsae was present in each of the ten codling moth populations sampled (93). The incidence of infection in these populations varied from 1.5 to 89.3\%; highest infections occurred at the end of the season in second generation fifth instar larvae, which also is the overwintering stage. Mortality was $58.9 \%$ during the overwintering stage, but this was due less to microsporidiosis than to both solitary and mixed infections by the fungus Beauveria bassiana. Apparently, infections by $N$. carpocapsae predisposed the overwintering larvae to the fungus. Also, the incidence of microsporidiosis was considerably higher and increased during the season in private orchards where insecticides were not used. In commercial orchards, the incidence of infection was much lower and remained constant during the entire season, indicating that the infected larvae were selectively killed by the insecticide.

ROW CROP PESTS Studies between 1954 and 1962 established that the most important factors affecting the natural host-pathogen relationships between Nosema pyrausta and the European corn borer, Ostrinia nubilalis, are $(a)$ effective transmission and spread of the pathogen vertically from parent to offspring and horizontally between adults or larvae; $(b)$ reductions in numbers of larvae that, because of the infections, are unable to attack a plant or develop into adults; and (c) a reduction in both vitality and fecundity exhibited by adults. Infection rates between 47 and $85 \%$ were observed in those earlier studies. (77).

Recent studies of the incidence of $N$. pyrausta in corn borer in North Dakota revealed that females from a disease-free population produced about twice as many eggs as females from populations with infected larvae (23). The infection rates varied from 12 to about $40 \%$ at five sites, and there was an inverse relationship between the average number of spores in larvae and the number of eggs produced by females at the five sites.

In Minnesota, $66 \%$ of all deformed pupae were infected, as were $54 \%$ of the adults that were reared from larvae collected from the field (115). Infections in adults caused reduced adult longevity, a lower percentage of 
ovipositing females, lower individual fecundity, and a reduction in egg fertility. Females that contained more than 10 million spores produced less than half the number of eggs produced by disease-free females.

Surveys conducted in China revealed that 0 to $6 \%$ of $O$. nubilalis in low density populations were infected with $N$. pyrausta, whereas 16 to $38 \%$ were infected in high density borer populations (15); the microsporidium apparently exerts a significant amount of control on natural corn borer populations. Similarly, in France Lipa (66) found 11 of 30 corn borer larvae and pupae infected with $N$. pyrausta during September 1974. The other 19 insects were infected with the previously undescribed species Thelohania ostriniae (= Vairimorpha necatrix). Also, infections were not observed in any of about 900 corn borers collected in Poland during 1963-1976. He speculated that the pathogens were restricted to $O$. nubilalis populations in southern Europe.

A 16-year study of natural infection by $N$. pyrausta in 2 counties in Nebraska established that the microsporidium caused or at least contributed to declines in European corn borer populations (49). In peak years, the incidence of infection reached $100 \%$. It appeared that high host densities and widespread spatial distribution of corn borers were essential to the development of epizootics by $N$. pyrausta.

The com earworm, Heliothis zea, is commonly infected both in nature and in laboratory colonies by the microsporidium Nosema heliothidis (11). Examinations of moths collected by light traps revealed that the seasonal incidence of infection was seldom less than $10 \%$, averaged about $30 \%$, and increased to $84.9 \%$ among late season larvae during October. Because of a high frequency of infection in dead and moribund field-collected larvae, the microsporidium has been considered an important factor in the regulation of natural populations of $H$. zea. $N$. heliothidis appears to have a very narrow host range, since in nature it has been reported only from $H$. zea and Heliothis virescens. However, Campoletis soronensis, a hymenopteran parasitoid of $H$. zea, is also susceptible to infection (10).

$N$. heliothidis is particularly serious in laboratory colonies of $H . z e a$ when larval infection rates approach $100 \%$. The infections cause "locking" of copulating adults, thus interfering with the reproductive process (96). By selection of adults that produced disease-free progeny, the microsporidium can be eliminated from a laboratory colony (29). The fungicide, benomyl, which previously had been used effectively against microsporidiosis in the alfalfa weevil, Hypera postica, (50) was not effective in eliminating $N$. heliothidis from corn earworm (12).

Vairimorpha necatrix, a dimorphic spore-forming microsporidium previously named Nosema necatrix and Thelohania diazoma $(21,72,75,85)$, has been isolated from at least 14 species of field-collected lepidopteran larvae. 
However, infection in natural populations usually is infrequent and apparently is not important as a natural regulating factor of field crop pests (74).

GRASSHOPPERS Infections by Nosema locustae have been observed in at least 58 species of Orthoptera (38). Many host records occurred during a five-year study of the natural occurrence of the pathogen in southern Idaho (41). Infections varied markedly between the 52 permanent sampling sites but were most common at sites characterized by mixed vegetation that supported both consistent and moderate densities of several species of grasshoppers. The presence of three species, Oedaleonotus enigma, Melanoplus bivittatus, and Melanopolus sanguinipes, was important for the persistence and increase of infections by $N$. locustae. Generally, infections first appeared in $O$. enigma and $M$. bivittatus early in the season; these species produced inoculum for infection of $M$. sanguinipes, the predominant summer species, which then produced inoculum for infection of the next generation of early summer species. Although the incidence of infection among grasshoppers collected at all study sites during a season averaged only $8.11 \%$, the incidence of infection reached $95 \%$ at one sampling late in the season.

Grasshopper densities were highest during the second season but decreased greatly during the third year and were lowest during the fifth season. Infections, however, peaked in the fourth season, followed by a sharp decline in the fifth season. The pattern depicted a lag-type hostparasite density relationship which indicated that the microsporidium might have contributed to reduced grasshopper densities. Also the study demonstrated that early seasonal infection of nymphs was necessary for developing pathogen levels that might regulate the natural levels of grasshoppers.

MOSQUITOES As pointed out by McLaughlin (77), the aquatic environment involves very different host-pathogen relationships than those that occur in the terrestrial environment. For example, transovarial transmission is most important and probably is the only means, in some cases, to maintain the pathogen and to expand an epizootic to the point where the pathogen would have a visible controlling action on host densities. However, a laboratory simulation of a natural situation that involved only transovarial transmission demonstrated that a pathogen would be eliminated from such a mosquito population (2). In that study all factors, including the number of gonotropic cycles and total egg production by infected and uninfected females, were equal except for a single factor of $52 \%$ reduced viability of eggs from infected females. This suggests that another method of transmission has to be operative. Similarly, transovarial trans- 
mission of Nosema algerae in populations of Anopheles gambiae was not important or prominent because larvae from infected eggs did not survive (14). Instead, transmission occurred by regurgitation of spores from salivary gland infections into the feeding area of other larvae; also, transovum transmission occurred because spores were present on the external surface of the eggs. Surface contamination of eggs was confirmed when infections were prevented by washing eggs from infected females. The parasite was eliminated from a mosquito colony by these hygienic techniques. Surveys for pathogens of aquatic insects in tropical regions have yielded other microsporidians that are transmitted per os (35).

Although information on the role of microsporidia in regulating natural mosquito populations is lacking, epizootics have been reported in colonized mosquitoes. For example, Nosema algerae was described as a serious problem in a laboratory colony of Anopheles stephensi (101). Also, Nosema sp. (probably $N$. algerae) caused epizootics among colonized mosquitoes at the University of Maryland and at Walter Reed Army Institute of Research (34). Of four species of mosquitoes colonized at the Maryland facility, Anopheles gambiae were most heavily infected (100\%) and development to the adult stage was totally inhibited. The incidence of infection among Anopheles albimanus was $75 \%$, with few becoming adults. The incidence among adults of Anopheles stephensi and Anopheles quadrimaculatus was 49 and 39\%, respectively. At the Walter Reed facility colonies of Aedes, Anopheles, and Culex were maintained, but infections occurred only in the anophelines.

\section{APPLIED CONTROL WITH PROTOZOA}

\section{Boll Weevil}

McLaughlin $(77,78)$ reviewed the results of some important studies between 1965 and 1970 when baits were used to induce artificial epizootics in boll weevil (Anthonomus grandis) populations by the neogregarine Mattesia grandis and the microsporidium Glugea gasti. Application of the pathogen-bait formulation, which also contained feeding stimulant, resulted in 50 to $70 \%$ infection of weevils in the spring and fall populations. Such treatments suppressed populations and in one instance reduced the overwintering population by $96 \%$, compared to the $84 \%$ natural reduction in an untreated area. However, midseason boll weevils did not respond to the baits and neither control nor crop protection could be demonstrated. No additional studies on the microbial control of the boll weevil have been conducted since the initiation of a concentrated effort to eradicate this insect. 
In addition to providing some background for the use of baits, the studies of the boll weevil resulted in one of the first critical assessments of the economics of mass producing protozoans in vivo (79). In the production scheme approximately 100 larvae per plate were inoculated with about $10^{6}$ spores, which resulted in $100 \%$ infection. The spores were harvested about 12 to 14 days later from adult weevils and were formulated with the bait at concentrations capable of producing demonstrable weevil population suppression. At this concentration, $3.3 \times 10^{5}$ spores per $\mathrm{ml}$, the cost of production of $M$. grandis was estimated at $\$ 50.80 /$ acre and of $G$. gasti at about $\$ 1.24 /$ acre. The large difference between these costs was due to the relative efficiency of production, which in the case of $M$. grandis might be increased by using alternate hosts or by employing more efficient field application procedures, such as bait application around pheromone traps.

\section{Stored Product Pests}

Baits also have been used to introduce Mattesia trogodermae into populations of the stored product pest Trogoderma glabrum (91). It was known that males which were surface-contaminated with spores inoculated females while mating. However, the efficiency of the spore transfer was increased by releasing a natural female sex pheromone at the site where males became contaminated. A synthetic pheromone that induced males to attempt to copulate with the pheromone lure enhanced the pathogen transfer (92). During the copulation attempt, spores that entered the genital organs later were transmitted congenitally to females. Therefore, it was postulated that larvae of the subsequent generation could become infected by $(a)$ consuming food contaminated by contact with infected adults, $(b)$ consuming cadavers of infected adults, and (c) transovarial or transovum transmission. The results showed that male contamination at lures with the pheromone alone or pathogen alone did not increase the mortality rate beyond that among untreated beetles. Also, pathogen-pheromone treatment of high parental densities caused significantly lower $F_{1}$ and $F_{2}$ population densities, but the treatment had no effect on $F_{1}$ population densities when parental population densities were low (1/16 of high density level). Therefore, the main spore transfer pathways were larval consumption of cadavers or contaminated food; little or no transovarial or transovum transmission occurred.

These studies established the potential of using $M$. trogodermae to control various pest species in stored products. The attractiveness of $M$. trogodermae as a control agent is increased because it is specific for species of Trogoderma, it is not pathogenic in certain vertebrates (87), and it is fairly easy to produce in usable quantities (83). 


\section{Forest Insects}

Most studies of the application of microsporidia against forest insects have been with Nosema fumiferanae against the spruce budworm, Choristoneura fumiferana. The microsporidium has been successfully introduced into populations of the spruce budworm by spraying trees with an aqueous spore suspension $(110,111)$. In one test $1.8 \times 10^{11}$ spores per tree were applied to trees with fourth and fifth instar larvae and later to trees with sixth instar larvae. The early treatment resulted in about 2.5 -fold increased infection at 11 and 25 days, posttreatment. The later treatment did not increase the incidence of infection among larvae but did increase the incidence among adults and the offspring from those adults. Also, the incidence of infection was slightly higher among insects from one tree treated with a formulation containing an ultraviolet light protectant (Sandoz adjuvant V). Samples taken the following season also indicated that the earlier treatments caused highest increases, but not significantly higher than late sprays, over the natural incidence (112). Two years after treatment the incidence of infection among insects on treated trees were still somewhat higher than on untreated trees, but in that period the incidence of infections on check trees had increased almost to treated levels (109). For example, the percentages of infection for the season of application, one year later, and two years later, were 53.0, 52.4, and 53.8, respectively, among insects from treated trees, compared to $23.0,39.0$, and 48.0, respectively, among insects from untreated trees. This indicated that the treatments advanced the infection by two to three years.

In a similar study, $\boldsymbol{N}$. fumiferanae and Pleistophora schubergi were formulated separately in various concentrations in aqueous suspensions with $25 \%$ (vol/vol) molasses and $0.3 \%$ (wt/vol) IMC 90-001 sunlight protectant (Sandoz, Inc., Homestead, Florida) and were applied against young needle mining larvae on white spruce, Picea glauca, and balsam fir, Abies balsamea (113). The results with $N$. fumiferanae revealed that $(a)$ single applications of $2.5 \times 10^{10}$ spores per tree against second and third instar nymphs did not increase infection over the natural level; $(b)$ later applications against fourth and fifth instar larvae, either alone or with a prior application against second and third instar larvae, significantly increased the incidence of infection; (c) single applications of doubled spore dosages, $5.0 \times 10^{10}$ spores per tree, increased infections over lower spore dosages, but not significantly; and $(d)$ the incidence of infection among insects in treated balsam fir trees was higher ( $72.9 \%$ at 25 days postapplication) than among insects in treated spruce trees (59.7\% at 25 days postapplication). However the natural incidence of infection among insects from untreated balsam fir trees (38.8\%) also was higher than among insects from untreated spruce trees $(25.4 \%)$. 
At 18 and 25 days postapplication of $P$. schubergi $(a) 61.2$ and $40.1 \%$, respectively, of larvae on white spruce (each treated with $2.5 \times 10^{10}$ spores) were infected, (b) 64.8 and $48.6 \%$, respectively, of larvae on white spruce trees (each treated with $5.0 \times 10^{10}$ spores) were infected, and (c) 96.3 and $95.2 \%$, respectively, of larvae on balsam fir (each treated with $5 \times 10^{10}$ spores) were infected. All applications were against fourth and fifth instar nymphs, and natural infections by $P$. schubergi were virtually nonexistent. These studies showed that the incidence of $N$. fumiferanae could be increased by applications against late instar larvae and that comparatively high levels of infections by $P$. schubergi could be established by such applications.

$P$. schubergi infects a wide variety of forest Lepidoptera and Hymenoptera $(53,103,105)$ and it has been tested against second and third instar larvae of Anisota senatoria and first instar Symmerista canicosta on northern red oak trees (54). The spores were formulated as aqueous sprays with a spreader-sticker or with the spreader-sticker plus a UV protectant (Sandoz "Shade"). The UV protectant increased persistence significantly and resulted in more than eight-fold increased infectivity at four days postapplication. Tests for control of $A$. senatoria and $S$. canicosta using formulations of $2 \times 10^{8}$ or $2 \times 10^{7}$ spores per $\mathrm{ml}$ with only the spreader-sticker resulted in 95.8 and $72.0 \%$ infection, respectively, among $A$. senatoria and $100 \%$ infection, for both treatments, among $S$. canicost $a$ at 14 days postapplication. Infections were not observed in insects collected from untreated trees. $P$. schubergi has been combined with Nosema disstriae in equal concentrations and in mixtures of $96 \% P$. schubergi and $4 \% N$. disstriae in aqueous sprays of $50 \%$ molasses with $0.3 \%$ IMC 90-001 UV protectant and applied at the rate of $1.8 \times 10^{11}$ spores per trembling aspen, Populus tremuloides, against the forest tent caterpillar, Malacosoma disstria (114). The formulation with equal concentrations of spores caused $76.1 \%$ infection by $P$. schubergi, compared to no natural infection, but did not increase infection by $N$. disstriae over the natural incidence. The formulation with unequal spore concentrations produced similar results with a slightly higher incidence of infection $(85.0 \%)$ by $P$. schubergi.

The reports of field tests with $N$. fumiferanae and $P$. schubergi showed significant increases in infection but no evidence of mortality or population control. The effect of infection on mortality and control was evident in a laboratory study in which second and fourth instar larvae naturally infected with $N$. fumiferanae were each inoculated with $5 \times 10^{4}, 5 \times 10^{6}$, or $5 \times 10^{8}$ spores of $P$. schubergi (108). Treatment of second instar larvae increased mortality during the subsequent instars, but only the highest dosage resulted in increased mortality when fourth instar larvae were inoculated. This also was demonstrated in a study in which spruce budworm with or 
without natural infection were inoculated with $2.0 \times 10^{5}$ spores of $N$. fumiferanae (107). Inoculation of previously uninfected larvae significantly lowered fecundity and pupal weights. Natural infections caused significantly lowered pupal weights, lowered fecundity, and lowered adult life span. Superimposed inoculation of naturally infected larvae enhanced the severity of these effects. The above studies demonstrate some potential control of forest insects by these microsporidia.

\section{Row Crop Pests}

Although Nosema pyrausta is an effective natural control of the European corn borer, Ostrinia nubilalis (63), the seriousness of infection by the microsporidium often depends on the interaction with additional stress factors, such as crowding or the resistance of maize plants to corn borer feeding $(62,71)$. For example, both leaf-feeding resistance and sheath-collar feeding resistance, which inhibit feeding by the first and second generation borers, respectively, together with heavy infections by $N$. pyrausta, decrease the number of larvae per plant and the weight of surviving larvae. Different inbred lines of leaf-feeding resistant varieties of maize did not influence the levels of infection, whereas the degree of sheath-collar feeding resistance had a direct influence on the severity of the infection. Thus, the interaction between infection and resistance was evaluated when $N$. pyrausta was applied early in the season to a large segment of the feral corn borer population (63). During the first year of the tests, treatments of $22.5 \times 10^{7}$ spores per plant in $25 \mathrm{ml}$ of distilled water, applied to plants artificially infested with egg masses free of $N$. pyrausta, resulted in significantly fewer larvae and borer cavities per plant. Also, the average weights of larvae from treated plants were lower than those of larvae from untreated plants, and $62.1 \%$ of the larvae from treated plants were infected compared to $1.5 \%$ of the larvae from untreated plants. During the second year, applications of 24.3 $\times 10^{7}$ spores per plant against simulated first-generation borers (artificially infested plants) failed to reduce the number of borers per plant but decreased the number of cavities per plant and caused a 7-fold increase in incidence of infection among the larvae. Also during the second year, foliar applications of $24.3 \times 10^{7}$ spores per plant against simulated second generation larvae reduced larval weights and the number of larvae and cavities per plant, but not significantly below those in untreated plants. However, the treatments caused 95.2 to $99.2 \%$ infection among larvae from treated plants compared to $20.8 \%$ infection among larvae from untreated plants.

In a recent test, insecticides were integrated with $N$. pyrausta in control of the corn borer (70). For 2 seasons, artificially infested corn plants were first treated with $1.2 \times 10^{7}$ spores; the next day they were treated with 
Bacillus thuringiensis var. kurstaki, carbaryl, or carbofuran. In each instance larval densities were reduced following applications of $N$. pyrausta and an insecticide. Combinations of the microsporidium with $B$. thuringiensis or carbaryl were more effective than its combination with carbofuran. Generally, these mortality factors acted independently with additive effects. This study indicates a good potential for developing an integrated approach using various combinations of mortality factors, including $N$. pyrausta, for control of the European corn borer.

As with any microbial agent, the manner by which $N$. pyrausta is transmitted in the field is an important factor in persistence following application. Transovarial transmission of $N$. pyrausta to the filial generation had been established in early studies $(56,116)$. Recently, Lewis (60) demonstrated that infected larvae migrate to other corn plants and distribute frass contaminated with spores, which are then consumed by uninfected larvae. This form of transmission resulted in high incidence of disease, high levels of infection, and reduced larval populations.

The dimorphic microsporidian Vairimorpha necatrix, which is considered to be a good prospect for microbial control of numerous lepidopterous pests (74), also infects the corn borer (61). Inoculation of neonate corn borer larvae resulted in $51 \%$ mortality as first instar larvae, due primarily to septicemia, and total inhibition of reproduction. The median effective doses at which reproduction subsequently was inhibited for first, second, or third instar larvae were $1.5,48.7$, and 1385.2 spores $/ \mathrm{mm}^{2}$ of media surface, respectively, compared to doses of $15.3,1055.3$, and 54729 spores $/ \mathrm{mm}^{2}$, respectively, at which pupation was inhibited. Infection of the first, second, and third instar larvae resulted in $76 \%, 92 \%$, and $96 \%$ infection, respectively, of adults. However, unlike $N$. pyrausta, $V$. necatrix is not transmitted either transovarially or transovum, or between larvae via fecal contamination. Instead it is transmitted when larvae consume infected cadavers or food contaminated with spores from cadavers.

At least 35 other species of Lepidoptera are susceptible to infection by $V$. necatrix, including such important agricultural pests as Pseudaletia unipuncta, Heliothis zea, Heliothis virescens, Autographa californica, Trichoplusia ni, Spodoptera frugiperda, Spodoptera exigua, Spodoptera ornithogalli, Plathypena scabra, Pseudoplusia includens, and Hyphantria cunea (74), and it appears that $V$. necatrix is useful against the black cutworm, Agrotis ipsilon (51). However, not all Lepidoptera are susceptible to infection $(52,72,75)$, nor are hymenopteran parasites $(26)$ or insects of other orders (75).

In a preliminary test, spores of $V$. necatrix applied in a spray formulation at the rate of about $3.9 \times 10^{11}$ spores/acre provided significant reduction of the tobacco budworm, Heliothis virescens, but control was not compara- 
ble to that by the chemical methomyl (80). Also, the application of $V$. necatrix on late cabbage infested with Trichoplusia $n i$ and Pieris rapae significantly reduced the populations of $T . n i$ and feeding on lower leaves and provided crop protection that compared favorably with the protection by applications of Autographa californica virus (72). The microsporidium had no effect on $P$. rapae in laboratory tests, and thus it was combined with a granulosis virus of $P$. rapae for integrated control of both insects.

Fuxa (24) found that $V$. necatrix interacted differently with various pathogens and at varying dosages in infection of Heliothis zea. For example, in combination with a commercial preparation of Bacillus thuringiensis, mixed interactions resulted that tended to be synergistic. Combination with a commercial preparation of $\mathrm{H}$. zea baculovirus resulted in definite antagonistic interactions. In combination with the fungus Nomuraea rileyi the interactions varied from synergistic at low dosages to antagonistic at high dosages. Graphic analysis of the interactions provided basically similar conclusions, but the author suggested that alteration of the bioassay inoculation system might have provided a more accurate picture of the interactions. Specifically, concentrating the inoculum on a smaller media surface (84) or better dispersion of the inoculum throughout the media might have produced less variation within the test groups.

A critical problem in the use and application of $V$. necatrix, as with many microbials, is loss of activity of spores due to UV radiation following application. The viability of dried spores of $V$. necatrix, as well as spores of Nosema trichoplusiae, declined within several hours after exposure to direct sunlight on corn leaves or on artificial diet $(72,73)$. Mixing spores with sterile soil provides some protection against UV inactivation. Kaya (55) reported that spores of $V$. necatrix survived in the field on leaves of bean plants for more than 28 hours and that survival was better both on the undersurfaces of the leaves and when formulated with a UV protectant. In the laboratory, spores suspended in water and exposed to short and long UV wave lengths were bioassayed in the salt marsh caterpillar Estigmene acrea. Spores exposed to short wave lengths $(254 \mathrm{~nm})$ lost activity within $10 \mathrm{~min}$, whereas spores exposed to long wave lengths $(366 \mathrm{~nm})$ remained viable after 360 min exposure. Spores were able to withstand short wave length radiation better when sprayed onto bean leaves. Kaya (54) had previously demonstrated that spores of Pleistophora schubergi were more sensitive to UV radiation than were spores of $V$. necatrix but that they were less sensitive when combined with a UV protectant.

Fuxa \& Brooks (25) also reported that the viability of spores of $V$. necatrix declined rapidly after two days on foliage of tobacco, cotton, or soybeans. However, some spores remained viable for 10 days on soybean foliage. Spores were inactivated more rapidly on cotton foliage than on tobacco or soybean foliage. Two UV protectants, Shade ${ }^{\circledast}$ (International 
Minerals and Chemical Corp., Libertyville, Illinois) combined with a sticker-spreader Triton X-100 (Rohm and Hass Co., Philadelphia, Pennsylvania) and San 285 AD WP66 (Sandoz-Wander, Inc., Homestead, Florida) afforded approximately equal protection for spores.

In subsequent study, control by $V$. necatrix in spray formulations (with the UV protection of SAN 285) and on corn meal baits was compared with control provided by a commercial formulation of $B$. thuringiensis in Triton X-100 plus Shade, and the chemical insecticide methomyl (26). Although the spray formulations resulted in up to $63.2 \%$ infection of corn earworm larvae, protection to flue-cured tobacco was not evident. However, an application of spores formulated with corn meal provided protection comparable to that provided by the chemical insecticide and commerical bacterial formulations. Treatment of soybeans or sorghum with aqueous spray formulations containing $3.2 \times 10^{13}$ spores/ha resulted in as much as $96 \%$ infection of larvae of $\mathrm{H}$. zea and the green cloverworm, Plathypena scabra; however, again there was no evidence of crop protection, even in the presence of a significant reduction in the number of larvae of $P$. scabra. Although the chemical methomyl provided better control, resurgence of $H$. zea in methomyl-treated plots resulted in more larvae in these plots than in those treated with $V$. necatrix. Also, infections were not observed in the hymenopteran parasites Campoletis sonorensis and Cardiochiles nigriceps reared from heavily infected tobacco budworms, $H$. virescens. $C$. sonorensis has been shown to be susceptible to Nosema heliothidis from $H$. zea $(10,11)$.

In addition to a wide host range, the relative ease of mass producing spores is another reason $V$. necatrix is particularly attractive as a microbial insecticide. Inoculation of third instar $H$. zea larvae on artificial diet produced $1.7 \times 10^{10}$ spores per larva at 15 days, which was a $3.3 \times 10^{6}$-fold increase over the inoculation dose (27). The study also demonstrated excellent storage of spores on dry corn meal for 10 months. Survival was best when spores were stored at $-15^{\circ} \mathrm{C}$ in water, water plus glycerin, cadavers, cadavers in glycerin, and lyophilized cadavers. $V$. necatrix is very sensitive to germicides and various other chemicals, which is critical because bacterial and fungal contaminants in spore preparations are important factors in loss of viability $(57,86)$. However, the antibiotics tetracycline, neomycin, and kanamycin effectively controlled bacterial and fungal contaminants without adversely affecting spore viability (86).

\section{Grasshoppers}

Three species of microsporidia, Nosema locustae, Nosema acridophagus, and Nosema cuneatum, appear promising as microbial agents for use against grasshoppers and possibly against certain economically important crickets. However, $N$. locustae has received the most attention because it 
infects numerous Orthoptera and is easily mass-produced in certain species of grasshoppers $(38,39,45)$. Field tests with small plots (4 to 40 ha) have demonstrated that applications of about $2.5 \times 10^{9}$ spores on $2 \mathrm{~kg}$ of wheat bran per ha at the time when important summer species, such as Melanoplus sanguinipes, are mostly third instar nymphs results in about $50 \%$ reduction within 4 weeks and 30 to $50 \%$ infection in certain predominant species $(40$, 42,48 ). Timing is important, as early applications against young grasshoppers cause more mortality initially but less infection later, whereas later applications cause less mortality initially but more infection later. Also, application against third instars maximizes both mortality and infection four weeks later when grasshoppers become adults and are beginning to oviposit. Mortality due to infections continues during the adult stage, but more importantly reproduction is reduced significantly $(20,45)$.

For most field tests, spores were applied on a wheat bran carrier. However, because wheat bran is more expensive to handle and to apply than are ultra low volume (ULV) sprays, which are the common means of applying chemicals in large-scale programs for grasshopper control, a study was conducted comparing the two methods (46). Three spore concentrations in ULV sprays were compared to the standard treatment on wheat bran of $2.5 \times 10^{9}$ spores/ha. Both infection and mortality:were higher in treatments of the wheat bran formulation than even the highest dosage of $2.5 \times 10^{10}$ spores/ha in sprays. The data indicated that at least 15 -fold increase in spores would be required in ULV sprays to achieve results comparable to spores on wheat bran. Cost comparisons revealed that the expense of producing 15 times more spores for spray formulations was much higher than the added cost of handling and applying wheat bran. Applying spores on rolled barley produced results comparable to treatment by spore-wheat bran formulations; such applications may be more economical if ground application (45) is used.

As with most protozoans, $N$. locustae is not particularly virulent and therefore is most useful as a long-term control agent of rangeland grasshop-: pers. The original intent was to apply $N$. locustae to areas: of increasing grasshopper densities and thereby prevent or reduce the magnitude of out-breaks. However, experience has shown that because of the unpredictability of grasshopper densities from one year to the next, ranchers and other rangeland managers will not enter into control programs unless the loss of significant amounts of forage is imminent. In such instances, some immediate population suppression is necessary to reduce densities to or near tolerable economic levels. $N$. locustae alone will not accomplish this, even by applying much heavier concentrations of spores. Recent studies have established that $N$. locustae is compatible with low concentrations (10\% actual ingredients) of chemical insecticides such as malathion (82), carbaryl, dime- 
thoate, and carbofuran (81). Field tests have demonstrated that $N$. locustae -wheat bran formulations can be tank mixed with chemical insecticidewheat bran formulations for simultaneous application; thus, significant short-term control is followed by added population control from $N$.' locustae. This integrated approach appears to be the most effective use of $N$. locustae.

As with $V$. necatrix, one of the favorable attributes of $N$. locustae is the ease of mass production. Two species of grasshoppers, Melanoplus bivittatus and Melanoplus differentialis, appear particularly well suited for this purpose because they withstand heavy spore concentrations. Average production of $3.9 \times 10^{9}(45)$ spores per grasshopper has been achieved and this represented a $5 \times 10^{6}$-fold increase over the number of spores used for inoculation. However, with improvements in the rearing system, average spore levels of $8.0 \times 10^{9}$ should be expected. Concentrations of $2.0 \times 10^{10}$ spores have been recovered from heavily infected females.

Results of a series of standard toxicological tests on vertebrates and certain invertebrates (bees) that establish noninfectivity of nontarget organisms have been included with efficacy reports that are available to potential registrants [Federal Register 44(32):9609-10, Wednesday, February 14, 1979]. Recently the Environmental Protection Agency approved a request for an exemption from the requirement of a tolerance in using $N$. locustae to control rangeland grasshoppers. [Federal Register 45(94):31312-12, Tuesday, May 13, 1980].

Nosema cuneatum and Nosema acridophagus are considerably more virulent in grasshoppers than is $N$. locustae (43). However, possibly because of the high virulence, production of sufficient spores for field tests is difficult, and cost of spore production in grasshoppers for commercial use may be prohibitive even though fewer spores might be required for applied use because of their higher virulence. However, studies which established that $N$. cuneatum and $N$. acridophagus were infective for the corn earworm also revealed that more $N$. acridophagus can be produced per insect in the corn earworm than in grasshoppers but that both insects produced about equal concentrations of $N$. cuneatum (47). Because corn earworms are easier to rear than are grasshoppers and the rearing time (inoculation to harvest) is shorter, producing these microsporidians in corn earworms may be less expensive. Also, spores of each species from corn earworms are more virulent to grasshoppers than are spores produced in grasshoppers.

\section{Mosquitoes}

Although there has been much interest in using protozoa to control mosquitoes, few field tests have been conducted. In one test, Plistophora (= Vavraia) culicis was applied to small pools of water inhabited with Culex 
pipiens fatigans ( $=C$. quinquefasciatus) (88). Applications of about 6,000 to 7,000 spores per $\mathrm{ml}$ to the mosquito breeding pools resulted in infections ranging from $0 \%$ to about $30 \%$. The microsporidium persisted for 24 months postinoculation at one test site and short-term population suppression was evident at several test sites; however, long-term control did not occur.

In addition to $P$. culicis, there has been considerable interest in Nosema algerae, the microsporidium described from a laboratory colony of Anopheles stephensi (101). This species exhibits a high pathogenicity for anopheline mosquitoes (3) that can interfere with the ability of mosquitoes to vector malarial organisms (90). Also, $N$. algerae can be grown in the corn earworm (100) which produces considerably higher yields of spores than is possible from mosquito larvae. $N$. algerae was infectious following injection into 11 species of insects and a crayfish (100) and following per os inoculation of a wide-range of mosquitoes, several species of muscoid flies, and a chironomid (89). In addition, one of nine species of predators of mosquitoes also was susceptible to per os inoculation (18).

In a field test against Anopheles albimanus in Panama, $\boldsymbol{N}$. algerae was applied to plots at rates of $2.15 \times 10^{7}$ to $2.15 \times 10^{9}$ spores per $\mathrm{m}^{2}(3)$. Depending on dosage, infection rates were as high as $86 \%$, with some mortality among larvae with massive spore concentrations. Although these tests demonstrated a potential for using $N$. algerae in control of mosquitoes, subsequent tests have produced varying results because the spores of $N$. algerae, as well as other potentially useful protozoa such as $P$. culicis, do not persist long in the feeding horizon of mosquito larvae. Accordingly, further testing of these organisms will depend on the development of a formulation that will prevent the spores from sinking to the bottom of the bodies of water to which they are applied.

\section{CONCLUDING REMARKS}

Significant progress was made during the past decade on natural and applied control of insects by protozoa. Insights into the mechanisms by which protozoa regulate insect populations have been provided. More importantly, research is showing that protozoa can be used effectively and effciently to control the densities of noxious insects.

As the body of information expands, aspects of applied use of protozoa that require more attention are becoming increasingly clear. Production of some organisms in quantities required for general use will be difficult. This might be solved by using alternative host species, but more effort on the in vitro growth of certain entomophilic protozoa is warranted. Conventional chemical insecticide formulation and application technology will not be 
applicable to protozoa. Rather, the research is showing increased efficacy when protozoa are applied in baits or on particulate carriers. Development of new (and possibly specific) formulation and application techniques and equipment will be required. Because of the characteristically low virulence expressed by most protozoa, few, if any, will be used alone against insect pests. Instead, they will be integrated with other control agents that will either provide some short-term control or will predispose the insects to control by the protozoa. Microbials have generally been evaluated against standards for relatively inexpensive, broad spectrum chemical insecticides; against such standards, few microbials could compete. Now, however, with increased concern for environmental quality and increasing cost of petrochemical products (which include most chemical insecticides), our standards are changing. There has been a significant increase in integrated pest management programs in which protozoa and other microbials can and will play a role. As this course continues, and as more protozoa are brought in to operational use, we will then be better able to evaluate the true potential of these organisms.

\section{Literature Cited}

1. Anderson, J. F., Magnarelli, L. A. 1978. Cometoides pechumani sp. n., a gregarine parasite of salt marsh deerflies. $J$. Invertebr. Pathol. 31:324-28

2. Andreadis, T. G., Hall, D. W. 1979. Significance of transovarial infections of Amblyospora sp. in relation to parasite maintenance in the mosquito Culex salinarius. J. Invertebr. Pathol. 34: 152-57

3. Anthony, D. W., Savage, K. E., Hazard, E. I., Avery, S. W., Boston, M. D., Oldacre, S. W. 1978. Field tests with Nosema algerae Vavra and Undeen against Anopheles albimanus Wiedemann in Panama. Misc. Publ. Entomol. Soc. Am. 11:17-27

4. Beard, R. L. 1970. A coccidian parasite of Galleria mellonella. Proc. Int. Colloq. Insect Pathol., 4th, College Park, Md., pp. 43-47

5. Beesley, J. E. 1977. The life cycle of Rasajeyna nannyla $\mathrm{n}$. gen., $\mathrm{n}$. sp., a coccidian pathogen of Tipula paludosa Meigen. Parasitology 74:273-84

6. Beesley, J. E. 1977. The incidence of Rasajeyna nannyla in Tipula vittata at two sites in Northumberland, England. J. Invertebr. Pathol. 30:249-54

7. Beesley, J. E. 1978. Seasonal abundance of three life cycle stages of Rasajeyna nannyla in Tipula paludosa and T. vittata. J. Invertebr. Pathol. 31:255-59
8. Brooks, W. M. 1974. Protozoan infections. In Insect Diseases, ed. G. E. Cantwell, Vol. 1, Chap. 5, pp. 237-300. NY: Marcel Dekker

9. Brooks, W. M. 1979. Production and efficacy of protozoa. Biotechnol. Bioeng. 22:91-116

10. Brooks, W. M., Cranford, J. D. 1972. Microsporidiosis of the hymenopterous parasites, Campoletis sonorensis and Cardiochiles nigriceps, larval parasites of Heliothis species. J. Invertebr. Pathol. 20:77-94

11. Brooks, W. M., Cranford, J. D. 1978. Host-pathogen relationships of Nosema heliothisis Lutz and Splendore. Misc. Publ. Entomol. Soc. Am. 11:51-63

12. Brooks, W. M., Cranford, J. D., Pearce, L. W. 1978. Benomyl: Effectiveness against the microsporidian Nosema heliothidis in the corn earworm Heliothis zea. J. Invertebr. Pathol. 31:239-45

13. Canning, E. U. 1964. Observations on the life history of Mattesia trogodermae sp. n., a schizogregarine parasite of the fat body of the khapra beetle Trogoderma granarium. J. Insect Pathol. 6:305-17

14. Canning, E. U., Hulls, R. H. 1970. A microsporidian infection of Anopheles gambiae Giles from Tanzania. Interpretation of its mode of transmission and notes on Nosema infections in mosquitoes. J. Protozool. 17:531-39 
15. Chiang, H. C., Huffaker, C. B. 1976. Insect pathology and microbial control of insects in the People's Republic of China. Proc. Int. Colloq. Invertebr. Pathol., 1st, Kingston, Ontario, Canada, pp. 42-46

16. Davies, K. A. 1973. Observations on Malameba locustae in Chortoicetes terminifera cultures in Australia. J. Invertebr. Pathol. 22:475

17. Donaldson, J. M. I. 1971. Attempts to hatch cysts of Malameba locustae (King \& Taylor) or control them with drugs. Phytophylactica 3:103-6

18. Esson, F. W. van, Anthony, D. W. 1976. Susceptibility of nontarget organisms to Nosema algerae, a parasite of mosquitoes. J. Invertebr. Pathol. 28: 77-85

19. Evans, W. A., Elias, R. G. 1970. The life cycle of Malamoeba locustae (King \& Taylor) in Locusta migratoria migratorioides (R. et F.). Acta Protozool. 7:229-41

20. Ewen, A. B., Mukerji, M. K. 1980. Evaluation of Nosema locustae as a control agent of grasshopper populations in Saskatchewan, J. Invertebr. Pathol. 35:295-303

21. Fowler, J. L., Reeves, F. L. 1974. Spore dimorphism in a microsporidian isolate. J. Protozool. 21:538-42

22. Franz, J. M., Huger, A. M. 1971. Microsporidia causing the collapse of an outbreak of the green tortrix (Tortrix viridana L.) in Germany. Proc. Int. Collog. Insect Pathol., 4th, College Park, Md., pp. 48-53

23. Frye, R. D., Olson, L. C. 1974. Fecundity and survival in populations of the European corn borer infected with Perezia pyraustae. J. Invertebr. Pathol. 24:378-79

24. Fuxa, J. R. 1979. Interactions of the microsporidium Vairimor pha necatrix with a bacterium, virus, and fungus in Heliothis zea. J. Invertebr. Pathol. 33:316-23

25. Fuxa, J. R., Brooks, W. M. 1978. Persistence of spores of Vairimorpha necatrix on tobacco, cotton, and soybean foliage. J. Econ. Entomol. 71:169-72

26. Fuxa, J. R., Brooks, W. M. 1979. Effects of Vairimorpha necatrix in sprays and corn meal on Heliothis species on tobacco, soybeans, and sorghum. J. Econ. Entomol. 72:462-67

27. Fuxa, J. R., Brooks, W. M. 1979. Mass production and storage of Vairimorpha necatrix. J. Invertebr. Pathol. 33:86-94

28. Hall, I. M., Stewart, F. D., Arakawa, K. Y., Strong, R. G. 1971. Protozoan para- sites of species of Trogoderma in Califomia. J. Invertebr. Pathol. 18:252-59

29. Hamm, J. J., Burton, J. L., Young, J. R., Daniel, R. T. 1971. Elimination of Nosema heliothidis from a laboratory colony of the corn earworm. J. Econ. Entomol. 64:624-27

30. Hanrahan, S. A. 1975. Ultrastructure of Malameba locustae (K. \& T.), a protozoan parasite of locusts. Acrida 4: 235-49

31. Harry, O. G. 1970. Gregarina: Their effect on the growth of the desert locust (Schistocerca gregaria). Nature 225: 964-66

32. Harry, O. G., Finlayson, L. H. 1975. Histopathology of secondary infections of Malpighamoeba locustae in the desert locust, Schistocerca gregaria. J. Invertebr. Pathol. 25:25-33

33. Harry, O. G., Finlayson, L. H. 1976. The life cycle, ultrastructure, and mode of feeding of the locust amoeba $\mathrm{Mal}$ pighamoeba locustae. Parasitology 72: $127-35$

34. Hazard, E. I. 1970. Microsporidian diseases in mosquito colonies: Nosema in two Anopheles colonies. Proc. Int. Colloq. Insect Pathol., 4th., College Park, Md., pp. 267-71

35. Hazard, E. I. 1975. The use of Microsporida for the control of aquatic insect pests. Proc. Conf. Impact of Use of Microorg. on Aquatic Environ., US Environ. Prot. Agency, Corvallis, Oreg., pp. 69-76

36. Hazard, E. I. 1980. Identification of Microsporidia. In Microbial Control of Pests and Plant Diseases 1970-1980, ed. H. D. Burges, Chap. 9. In press

37. Henry, J. E. 1968. Malameba locustae and its antibiotic control in grasshoppers. J. Invertebr. Pathol. 11:224-33

38. Henry, J. E. 1969. Extension of the host range of Nosema locustae in Orthoptera. Ann. Entomol. Soc. Am. 62:452-53

39. Henry, J. E. 1969. Protozoan and viral pathogens of grasshoppers. $\mathrm{PhD}$ thesis. Mont. State Univ., Bozeman. $153 \mathrm{pp}$.

40. Henry, J. E. 1971. Experimental application of Nosema locustae for control of grasshoppers. J. Invertebr. Pathol. 18: 389-94

41. Henry, J. E. 1972. Epizootiology of infections by Nosema locustae Canning in grasshoppers. Acrida 1:111-20

42. Henry, J. E., Oma, E. A. 1974. Effect of prolonged storage of spores on field applications of Nosema locustae against grasshoppers. J. Invertebr. Pathol. 23: 371-77 
43. Henry, J. E., Oma, E. A. 1974. Effects of infections by Nosema locustae Canning, Nosema acridophagus Henry, and Nosema cuneatum Henry in Melanoplus sanguinipes (Say). Acrida 3:223-31

44. Henry, J. E., Oma, E. A. 1975. Sulfonamide antibiotic control of Malameba locustae (King \& Taylor) and its effect on grasshoppers. Acrida 4:217-26

45. Henry, J. E., Oma, E. A. 1980. Protozoa: Pest control by Nosema locustae, a pathogen of grasshoppers and crickets. See Ref. 36, Chap. 30. In press

46. Henry, J. E., Oma, E. A., Onsager, J. A. 1978. Relative effectiveness of ULV spray applications of Nosema locustae against grasshoppers. J. Econ. Entomol. 71:629-32

47. Henry, J. E., Oma, E. A., Onsager, J. A., Oldacre, S. W. 1979. Infection of the corn earworm, Heliothis zea, with Nosema acridophagus and Nosema cuneatum from grasshoppers: Relative virulence and production of spores. $J$. Invertebr. Pathol. 34:125-32

48. Henry, J. E., Tiahrt, K., Oma, E. A. 1973. Importance of timing, spore concentrations, and spore carrier levels in applications of Nosema locustae for control of grasshoppers. J. Invertebr. Pathol. 21:263-72

49. Hill, R. E., Gary, W. J. 1979. Effects of the microsporidium, Nosema pyrausta, on field populations of European corn borers in Nebraska. Environ. Entomol. 8:91-95

50. Hsiao, T. H., Hsiao, C. 1973. Benomyl: A novel drug for controlling a microsporidian disease of the alfalfa weevil. $J$. Invertebr. Pathol. 22:303-4

51. Ignoffo, C. M., Garcia, C. 1979. Susceptibility of larvae of the black cutworm to species of entomopathogenic bacteria, fungi, protozoa, and viruses. J. Econ. Entomol. 72:767-69

52. Jacques, R. P. 1977. Field efficacy of virus infections to the cabbage looper and imported cabbageworm on late cabbage. J. Econ. Entomol. 70:111-18

53. Kaya, H. K. 1973. Pathogenicity of Pleistophora schubergi to larvae of the orange-striped oakworm and other lepidopterous insects. J. Invertebr. Pathol. 22:356-58

54. Kaya, H. K. 1975. Persistence of spores of Pleistophora schubergi in the field, and their application in microbial control. J. Invertebr. Pathol. 26:329,-32

55. Kaya, H. K. 1977. Survival of spores of Vairimorpha (=Nosema) necatrix exposed to sunlight, ultraviolet radiation, and high temperature. J. Invertebr. $\mathrm{Pa}$ thol. 30:192-98

56. Kramer, J. P. 1959. Some relationships between Perezia pyraustae Paillot and Pyrausta nubilalis (Hubner). J. Insect Pathol. 1:25-33

57. Kramer, J. P. 1976. The extra-corporeal ecology of microsporidia. In Comparative Pathobiology, Vol. 1. Biology of the Microsporidia, ed. L. A. Bulla Jr., T. C. Cheng, pp. 127-35. New York/London: Plenum

58. Larsson, R. 1976. Insect pathological investigations on Swedish Thysanura. 1. Observations on Malamoeba locustae from Lepisma saccharina. J. Invertebr. Pathol. 28:43-46

59. Lea, A. 1958. Recent outbreaks of the brows locust, Locustana pardalina (Walk.) with special reference to the influence of rainfall. J. Entomol. Soc. South. Afr. 21:18-35

60. Lewis, L. C. 1978. Migration of larvae of Ostrinia nubilalis infected with Nosema pyrausta and subsequent dissemination of this microsporidium. Con. Entomol. 110:879-900

61. Lewis, L. C., Gunnarson, R. D. 1978. Response of Ostrinia nubilalis to the microsporidium Vairimorpha necatrix. Proc. Int. Colloq. Invertebr. Pathol., Prague, pp. 109-10

62. Lewis, L. C., Lynch, R. E. 1976. Influence on the European corn borer of Nosema pyrausta and resistance in maize to leaf feeding. Environ. Entomol. 5:139-42

63. Lewis, L. C., Lynch, R. E. 1978. Foliar application of Nosema pyrausta for suppression of populations of European corn borer. Entomophaga 23:83-88

64. Lipa, J. J. 1966. The Nature of Infectious Processes Caused by Protoza in Insects, Final Rep. 1960-1965, Inst. Plant Prot., Lab. Biol. Control, Grunwaldzka 189, Poznan, Pol. 64 pp.

65. Lipa, J. J. 1976. Microorganisms in adults of several noctuid species (Noctuidae : Lepidoptera) caught in the light trap during 1973-1975. Bull. Biol. Pol. Sci. Ser. Sci. Biol. 24:783-87

66. Lipa, J. J. 1977. Thelohania ostriniae $n$. sp., a new microsporidian parasite of the European corn borer Ostrinia nubilalis Hbn. Acta Protozool. 16:151-55

67. Lipa, J. J., Carl, K. P., Valentine, E. W. 1977. Blastocrithidia caliroae sp. n., a flagellate parasite of Caliroa cerasi ( $\mathrm{L}$.) and notes on its epizootics in host field populations. Acta Protozool. 31:121-29

68. Lipa, J. J., Madziara-Borusiewicz, K. 1976. Microsporidians parasitizing the 
green tortrix (Tortrix viridana L.) in Poland and their role in the collapse of the tortrix outbreak in Puszcza Niepolomicka during 1970-1974. Acta Protozool. 31:529-36

69. Lipa, J. J., Smirnoff, W. A. 1971. Crithidia cimbexi sp. n., a new flagellate of Cimbex americana Leach. Bull. Acad. Pol. Sci. Ser. Sci. Biol. 19:269-74

70. Lublinkhof, J., Lewis, L. C., Berry, E. C. 1979. Effectiveness of integrating insecticides with Nosema pyrausta for suppressing populations of the European com borer. J. Econ. Entomol. 72:880-83

71. Lynch, R. E., Lewis, L. C. 1976. Influence on the European corn borer of Nosema pyrausta and resistance in maize to sheath-collar feeding. Environ. Entomol. 5:143-46

72. Maddox, J. V. 1966. Studies on a microsporidiosis of the armyworm Pseudaletia uni puncta (Haworth). $\mathrm{PhD}$ thesis. Univ. Ill., Urbana. 184 pp.

73. Maddox, J. V. 1977. Stability of entomopathogenic protozoa. Misc. Publ. Entomol. Soc. Am. 11:3-18

74. Maddox, J. V., Brooks, W. M., Fuxa, J. R. 1980. Vairimorpha necatrix, a pathogen of agricultural pests. See Ref. 36, Chap. 31. In press.

75. Maddox, J. V., Sprenkel, R. K. 1978. Some enigmatic microsporidia of the genus Nosema. Misc. Publ. Entomol. Soc. Am. 11:65-84

76. McLaughlin, R. E. 1965. Mattesia grandis n. sp., a sporozoan pathogen of the boll weevil Anthonomus grandis Boheman. J. Protozool. 12:405-13

77. McLaughlin, R.E. 1971. Use of protozoa for microbial control of insects. In Microbial Control of Insects and Mites, ed H. D. Burges, N. W. Hussey, 6:15172. London/New York: Academic. $861 \mathrm{pp}$.

78. McLaughlin, R. E. 1973. Protozoa as microbial control agents. Misc. Publ. Entomol. Soc. Am. 9:95-98

79. McLaughlin, R. E., Bell, M. R. 1970. Mass production in vivo of two protozoan pathogens, Mattesia grandis and Glugea gasti, of the boll weevil, $A n$ thonomus grandis. J. Invertebr. Pathol. 16:84-88

80. Mistric, W. J. Jr., Smith, F. D. 1973. Tobacco budworm: Control on fluecured tobacco with certain microbial pesticides. J. Econ. Entomol. 66:979-82

81. Mussgnug, G. L. 1980. Integration of Nosema locustae with chemical insecticides and entomopoxvirus for control of grasshoppers. PhD thesis. Mont. State Univ., Bozeman. $115 \mathrm{pp}$.

82. Mussgnug, G. L., Henry, J. E. 1979. Compatibility of malathion and Nosema locustae Canning in Melanoplus sanguinipes (F.). Acrida 8:77-81

83. Nara, J. M. 1975. Life history and spore production of Mattesia trogodermae Canning a pathogen of Trogoderma glabrum (Herbst). MS thesis. Univ. Wis., Madison. 63 pp.

84. Nordin, G. L. 1976. Microsporidian bioassay technique for third-instar Pseudaletia unipuncta larvae. J. Invertebr. Pathol. 27:397-98

85. Pilley, B. M. 1976. A new genus Vairimorpha for Nosema necatrix 1965. Pathogenicity and life cycle in Spodoptera exempta. J. Invertebr. Pathol. 28: $177-84$

86. Pilley, B. M. 1978. The storage of infective spores of Vairimorpha necatrix in antibiotic solution at $4^{\circ} \mathrm{C}$. J. Invertebr. Pathol. 31:341-44

87. Pounds, J. P. 1977. Safety and potential hazards of the entomopathogen Mattesia grandis to non-target species. PhD thesis. Univ. Wis., Madison. 242 pp.

88. Reynolds, D. G. 1972. Experimental introduction of a microsporidian into a wild population of Culex pipiens fatigans (Wied.). Bull. WHO 46:807-12

89. Savage, K. E. 1975 . Nosema algerae Vavra and Undeen 1970: Its bionomics and development for use as a biological control agent for mosquitoes. MS thesis. Univ. Fl., Gainesville. 86 pp.

90. Savage, K. E., Lowe, R. E., Hazard, E. I., Lofgren, C. S. 1972. Studies on the transmission of Plasmodium gallinaceum by Anopheles quad rimaculatus infected with a Nosema sp. Bull. WHO 45:845-47

91. Schwalbe, C. P., Burkholder, W. E., Boush, G. M. 1974. Mattesia trogodermae infection rates as influenced by mode of transmission, dosage, and host species. J. Stored Prod. Res. 10:61-66

92. Shapas, T. J., Burkholder, W. E., Boush, G. M. 1977. Population suppression of Trogoderma glabrum by using pheromone luring for protozoan pathogen dissemination. J. Econ. Entomol. 70:469-74

93. Simchuk, P. A., Sikura, A. I. 1978. The microsporidian Nosema carpocapsae Paillot and its importance as a regulation of the codling moth Laspeyresia pomonella. Entomol. Obozr. 57:495-99

94. Smirnoff, W. A., Lipa, J. J. 1970. Herpetomonas swainei $\mathrm{sp}$. n., a flagellate 
parasite of Neodiprion swainei. J. Invertebr. Pathol. 16:187-95

95. Sneller, V. 1979. Inhibition of Dirofilaria immitis in gregarine-infected Aedes aegypti: Preliminary observations. J. Invertebr. Pathol. 34:62-70

96. Snow, J. W., Lewis, W. J., Sparks, A. N. 1970. Mating of normal and sterilized olonized and native corn earworms with emphasis on failure of pairs to separate after copulation. J. Econ. Entomol. 63:873-76

97. Sprague, V. 1977. Systematics of the Microsporidia. In Comparative Pathobiology, Vol. 2. Systematics of the Microsporidia, ed. L. A. Bulla Jr., T. C. Cheng. New York: Plenum. 510 pp.

98. Tanada, Y. 1976. Epizootiology and microbial control. See Ref. 57, pp. 247-79

99. Thompson, H. M. 1960. The possible control of a budworm infestation by a microsporidian disease. Can. Dep. Agric. Bi-Mon. Prog. Rep. 16:1

100. Undeen, A. H., Maddox, J. V. 1973. The infections of non-mosquito hosts by infection with spores of the microsporidian Nosema algerae. J. Invertebr. Pathol. 22:258-65

101. Vavra, J., Undeen, A. H. 1970. Nosema algerae $\mathrm{n}$. $\mathrm{sp}$. a pathogen in a laboratory colony of Anopheles stephensi Liston. J. Protozool. 17:240-49

102. Venter, I. G. 1966. Egg development in the brown locust, Locustana pardalina (Walker) with special reference to the effect of infestations by Malameba locustae. South. Afr. J. Agric. Sci. 9: 429-34

103. Weiser, J. 1961. Die mikrosporidien als parasiten der insekten. Monogr. Angew. Entomol. 17, pp. 96-98

104. Wilson, G. G. 1973. Incidence of Microsporida in a field population of spruce budworm. Environ. Can. For. Serv. Bi-Mon. Prog. Rep. 29:35-36

105. Wilson, G. G. 1975. Occurrence of Thelohania sp. and Pleistophora sp. in Choristoneura fumiferana. Can. J. Zool. 53:1700-1802

106. Wilson, G. G. 1977. Observations of the incidence rates of Nosema fumiferanae in a spruce budworm, Choristoneura fumiferana population. Proc. Entomol. Soc. Ont. 108:144-45

107. Wilson, G. G. 1977. The effects of feeding microsporidian (Nosema fumiferanae) spores to naturally inf ected spruce budworm (Choristoneura fumiferana). Can. J. Zool. 55:249-50

108. Wilson, G. G. 1978. Detrimental effects of feeding Pleistophora schubergi to spruce budworm (Choristoneura fumiferana) naturally infected with Nosema fumiferanae. Can. J. Zool. 56:578-80

109. Wilson, G. G. 1978. Microsporidian infection in spruce budworm (Choristoneura fumiferana) 1 and 2 years after application. Bi-Mon. Res. Notes Can. For. Serv. 34:16

110. Wilson, G. G., Kaupp, W. J. 1975. Application of a microsporidia Nosema fumiferanae against spruce budworm on Manitoulin Island, 1975. Environ. Can. Inf. Rep. IP-X-11. 26 pp.

111. Wilson, G. G., Kaupp, W. J. 1976. A preliminary field trial using Nosema fumiferanae against the spruce budworm, Choristoneura fumiferana. BiMon. Res. Notes Can. For. Serv. 32:2-3

112. Wilson, G. G., Kaupp, W. J. 1976. Incidence of Nosema fumiferanae in spruce budworm Choristoneura fumiferana in the year following application. Bi-Mon. Res. Notes Can. For. Serv. 32:32

113. Wilson, G. G., Kaupp, W. J. 1976. Application of Nosema fumiferanae and Pleistophora schubergi against the spruce budworm in Ontario, 1976. Environ. Can. Inf. Rep. IP-X-15. 15 pp.

114. Wilson, G. G., Kaupp, W. J. 1977. Application of Nosema disstriae and Pleistophora schubergi against the forest tent caterpillar in Ontario, 1977. Forest Pest Manage. Inst., Sault Ste. Marie, Ont., Rep. FMP-X-4. 9 pp.

115. Windels, M. B., Chiang, H. C., Furgala, B. 1976. Effects of Nosema pyrausta on pupa and adult stages of the European corn borer Ostrinia nubilalis. J. Invertebr. Pathol. 27:239-42

116. Zimmack, H. L., Brindley, T. A. 1957. The effect of the protozoan parasite Perezia pyraustae Paillot on the European corn borer. J. Econ. Entomol. $50: 637-40$ 